\title{
PERCEIVED QUALITY AS A KEY ANTECEDENT IN CONTINUANCE INTENTION ON MOBILE COMMERCE
}

\author{
Hsiang-Ming Lee \\ Chien Hsin University of Science and Technology \\ No.229, Jiansing Rd., Jhongli City, Taoyuan County 320, Taiwan \\ hmlee@uch.edu.tw \\ Tsai Chen \\ Fo Guang University \\ No. 164 13F-1 Nanking E. Rd. Sec.5, Taipei, Taiwan \\ chenctn@yahoo.com.tw
}

\begin{abstract}
Based on the smart phone and $3 \mathrm{G}$ communication boom in recent years, mobile commerce has become increasingly popular. This study empirically investigated the continuance usage intention of $\mathrm{m}$-commerce consumers. The proposed model is an extension of the expectation-confirmation model, with perceived quality as the antecedent variable of confirmation and perceived usefulness. This model employed three dimensions of perceived quality from DeLone and Mclean's IS success model. Survey data were collected from a sample of $406 \mathrm{~m}$-commerce users and statistically analyzed using LISREL. Results show that perceived information, system, and service qualities all positively influence confirmation, whereas information and system qualities affect perceived usefulness. This study also validated ECM in the m-commerce context by showing that confirmation and perceived usefulness both have substantial influences on satisfaction, and in turn, affects continuance intention. The study draws attention to the importance of quality in retaining mobile commerce customers. Mobile commerce providers will benefit from our research results by knowing how to strengthen perceived qualities and increase customers' loyalty in the future.
\end{abstract}

Keywords: Mobile Commerce, Information Quality, System Quality, Service Quality, Expectation-Confirmation Model 


\section{INTRODUCTION}

Explosive growth in the usage and market penetration of mobile devices (e.g., mobile phones, personal digital assistants, and other handheld devices) is the driving force behind mobile commerce (m-commerce) $)^{1}$. The exponential increase of $\mathrm{m}$-commerce sales in the United States, with $91.4 \%$ and $73.1 \%$ increases estimated for 2011 and 2012, respectively, is primarily the result of increasing smartphone usage and mobile Internet usage ${ }^{2}$. By the end of 2011, there were 5.9 billion mobile cellular subscriptions worldwide, including 1.2 billion active mobile broadband subscriptions. Access to $3 \mathrm{G}$ mobile networks is now available to $45 \%$ of the global population. Asia and the Pacific have contributed greatly to this global phenomenon ${ }^{3}$. According to the National Communication Commission (NCC) of Taiwan, the number of $3 \mathrm{G}$ subscribers reached 20.9 million in 2011, representing a penetration rate of $76.9 \%$. Consequently, Taiwan has gained various advantages in developing m-commerce .

Although mobile telephones and other applications can be developed quickly and easily for m-commerce, it is important to have a deeper insight into consumers' perceptions and acceptance of m-commerce ${ }^{6}$. Previous research in this area has focused primarily on the adoption of $\mathrm{m}$-commerce. However, the success of the industry depends on customers' continuance intention and long-term use ${ }^{7}$. M-commerce users are irregular in their actions and they might not return to the action if they leave ${ }^{8}$. Thus, it is very important to maintain users' loyalty for the success of m-commerce'. Many studies tested information system continuance usage intention with the expectation-confirmation model (ECM). Integrating expectation-confirmation theory (ECT) from consumer behavior literature ${ }^{10}$ with the technology acceptance model (TAM) of information systems (IS) success ${ }^{11}$, ECM proposed that confirmation and perceived usefulness are two determinants of user satisfaction and subsequently post-purchase behavior (e.g., continuance intention) ${ }^{12,13,14,15}$. ECM has been proven to be successfully applied in various consumer-oriented online service contexts ${ }^{14}$, 16,17 . It is therefore a logical step to adopt and empirically test this model in $\mathrm{m}$-commerce, a form of wireless online service, in order to gain a deeper insight into continuance intention of $\mathrm{m}$-commerce as well as to enlarge ECM's application domain.

In addition to ECM, perceived quality may be a potential antecedent of long-term use. Perceived quality is an indispensable factor for mobile Internet providers because it helps them to acquire customers by satisfying them with their first time use. It also increases customer loyalty by encouraging customers to use the provider's services repeatedly in the future $^{18}$. Research on quality has focused mainly on relevant fields such as 
websites $^{19}$ and responsiveness ${ }^{20}$. DeLone and Mclean ${ }^{21,} 22$ postulated a model of information system (IS) success with system, information, and service qualities as quality dimensions. Because perceived quality is necessary for m-commerce success, it may also be a decisive factor of continuance usage. However, research in this area is lacking. Therefore, this study integrates the three dimensions of perceived quality of DeLone and Mclean $^{21,22}$ with ECM to investigate the determinants of consumer intentions to continue using m-commerce.

This study is organized as follows: literature on perceived quality and the expectation-confirmation model is reviewed. After the research model and hypotheses are proposed, an online survey was conducted with structural equation modeling as the statistical analysis technique applied to collected data. Lastly, there is a discussion of research results followed by a discussion of managerial implications, limitations and future research.

\section{LITERATURE REVIEW}

\subsection{Mobile Commerce}

Mobile commerce (m-commerce) represents the use of mobile devices (e.g., mobile phones, PDAs, and handheld computers) to conduct new types of e-commerce transactions using wireless telecommunication networks and other wired e-commerce technologies ${ }^{23}$. Thus, m-commerce is any type of service or transaction with economic value involving, at least on one end, wireless networks and mobile devices ${ }^{5}$.

M-commerce was initially expected to experience tremendous growth for several reasons, including the rapid growth of mobile phone adoption and its corresponding advantage of connecting with the community at any time and any place ${ }^{1}$. In addition, the improving safety of mobile payment has also resulted in increased use of handheld devices to deliver $\mathrm{m}$-commerce ${ }^{24}$. However, several factors may reduce the potential benefits of m-commerce by frustrating users: data transfer difficulties ${ }^{25}$, poor connectivity $^{26}$, and awkward device design features such as small screens, low-resolution displays, and tiny multifunction keypads ${ }^{23}$.

\subsection{Perceived Qualities}

Empirical research on m-commerce has shown that perceived system quality, defined by the authors as "the degree to which individuals perceive that the connection between a mobile device and the Internet is satisfying, in terms of transfer speed and reliability" ${ }^{, 2}$, has a significant effect on attitudes toward wireless financial services. This in turn has a positive effect on the usage intentions of consumers ${ }^{27}$. Chae et al. ${ }^{18}$, on the other hand, investigated the information quality of mobile Internet services and 
proposed a four-dimensional mobile service quality description consisting of connection quality, content quality, interaction quality, and context quality. "Information quality", however, is an umbrella term that typically only refers to connection quality, which represents uninterrupted accessibility to a mobile service that enables consumers to work in a stable environment. Although this is similar to parts of the above-mentioned perceived system quality $^{16}$, the terminology is rather confusing.

Consumers, irrespective of wired or wireless Internet access, are concerned not with how a service is provided, but with the resulting quality they receive ${ }^{15}$. Thus, research on IS quality and e-commerce success can be of great help in understanding consumer perceptions.

Based on research by Shannon and Weaver ${ }^{28}$ and information "influence" theory by Mason ${ }^{29}$, DeLone and Mclean ${ }^{21}$ postulated a model of information system (IS) success in which "system quality" measures technical success, "information quality" measures semantic success, and "use satisfaction, individual impacts" and "organizational impacts" measure effectiveness success. Pitt, Watson, and $\operatorname{Kavan}^{30}$ later argued that the measures seem strongly product-focused. Because service plays a vital role in IS effectiveness, they added "service quality" as another component of IS success. The updated model can be adapted to the measurement challenges of the B2C e-commerce world ${ }^{22}$.

In an e-commerce system, system quality refers to measures of the information processing system itself in terms of usability, availability, reliability, adaptability, and response time ${ }^{31}$. Information quality refers to measures of IS output, namely the quality of the information that the system produces primarily in the form of reports and captures "the content issue," which means that Web content should be personalized, complete, relevant, and easy to understand ${ }^{22}$. Finally, service quality measures the quality of the support system users receive from the IS department and IT support personnel $^{22}$. Previous research usually measures service quality with respect to responsiveness, assurance, and empathy ${ }^{22,32,33}$.

Using the three-dimensional quality concept from DeLone and McLean's model, another empirical study investigated the effect of Web site quality on customer conversion and retention and showed that, although the relationships were significant, online companies should focus on system quality to increase intention of initial purchase and on service quality for intention of continued purchase ${ }^{34}$.

\subsection{Expectation-Confirmation Model}

Bhattacherjee $^{16}$ proposed the expectation-confirmation model (ECM) by integrating expectation-confirmation theory (ECT) of consumer behavior 
literature ${ }^{10}$ with the technology acceptance model (TAM) of information systems (IS) success ${ }^{11}$. Bhattacherjee examined the cognitive beliefs and antecedents that influence intention to continue using IS. ECT was first theorized by Oliver ${ }^{10}$ and was frequently used to study consumer satisfaction and post-purchase behavior ${ }^{8}$. Consumers assess the perceived performance of a specific product or service in relation to their original expectation of their purchase, and then determine whether their expectations were met ${ }^{10,35}$. Confirmed or positive disconfirmed consumers experience "satisfaction," and satisfied consumers, in turn, form a repurchase intention. Dissatisfied users discontinue subsequent use ${ }^{10}$. Spreng, MacKenzie and Olshavsky (1996) ${ }^{36}$ further conceptualized two types of satisfaction, attribute satisfaction and information satisfaction, which are influenced by congruent desires and expectations. The continuance decision of IS users is similar to consumers' repurchase decisions because they both (1) follow an initial (acceptance or purchase) decision, (2) are influenced by the initial use (of IS or product) experience, and (3) can potentially lead to ex post reversal of the initial decision ${ }^{16}$. Drawing from the TAM ${ }^{11}$, Bhattacherjee ${ }^{16}$ suggested that post-consumption expectation can be represented as ex post perceived usefulness in the IS continuance model. Perceived usefulness is expected to influence users' post-acceptance affect (i.e., satisfaction) and continuance intention. Confirmation increases users' perceived usefulness, and negative confirmation reduces this perception.

The ECM emphasizes the importance of post-adoption expectation instead of pre-expectation ${ }^{13}$. Thus, the ECM suggests that an individual's intention to continue IS usage depends on three variables: the user's level of satisfaction with the IS, the user's confirmation of expectations, and post-adoption expectations in the form of perceived usefulness ${ }^{37}$. The ECM has also proven to be successful in various consumer-oriented online service contexts $^{14,16,17}$.

\section{RESEARCH MODEL AND HYPOTHESES}

The more that an individual forms a perception of a service or product's performance, the more likely it is that perceived performance will exceed expectation levels, leading to a positive relationship between perceived performance and disconfirmation ${ }^{38}$. Some studies have defined perceived performance as perceived quality. For example, Yen and $\mathrm{Lu}^{39}$ defined sellers' performance as bidders' perceptions of how the sellers meet their expectations of service quality and reputation in online auctions. Empirical research has shown that information and system qualities have significantly positive effects on disconfirmation ${ }^{40}$. Prior IS studies have demonstrated a positive effect of system quality on user satisfaction ${ }^{22,41}$. Service quality is also the main factor influencing consumer satisfaction 
with a Web site, which in turn determines their intention to repurchase on that Web site ${ }^{42,43}$. In industries apart from the computer industry, such as the insurance industry, service quality also influences consumer satisfaction and determines their repurchase intention ${ }^{44}$. All three qualities have significant influences on satisfaction in the e-commerce context ${ }^{45}$. In the ECM, satisfaction occurs only after an initial expectation is confirmed. Thus, confirmation can be considered a mediating variable between quality and satisfaction, leading to the following hypotheses:

Hla: Perceived information quality has a positive effect on confirmation in m-commerce.

H1b: Perceived system quality has a positive effect on confirmation in m-commerce.

H1c: Perceived service quality has a positive effect on confirmation in m-commerce.

Empirical research has shown that information quality is a major influence on the perceived usefulness of websites ${ }^{42,46}$, as suggested by Seddon ${ }^{47}$ and validated by Rai et al. ${ }^{41}$ concerning traditional IS. Because system quality is concerned primarily with the consistency of the interface and ease of use ${ }^{47}$ and perceived ease of use influences perceived usefulness $^{11}$, system quality likely has a positive effect on the perceived usefulness of an e-commerce system ${ }^{42}$. There is also a positive relationship between service quality and perceived usefulness ${ }^{48}$. In the study of mobile website adoption, Zhou ${ }^{49}$ also found that information quality, system quality and service quality all had positive effect on perceived usefulness. Therefore, this study proposes the following hypotheses:

H2a: Perceived information quality has a positive effect on perceived usefulness in m-commerce.

H2b: Perceived system quality has a positive effect on perceived usefulness in m-commerce.

H2c: Perceived service quality has a positive effect on perceived usefulness in m-commerce.

The research model in this study (Fig. 1) is an extension of the ECM based on the information quality of m-commerce. Because the ECM is used as the baseline model of this study and service repurchase intention among mobile Internet users is significantly related to satisfaction ${ }^{50}$, this study verifies the hypothesized relationships of the ECM in the m-commerce context.

H3: Users' extent of confirmation is positively associated with their perceived usefulness of m-commerce approach.

H4: Users' extent of confirmation is positively associated with their 
perceived satisfaction of m-commerce approach.

H5: Users' perceived usefulness of m-commerce approach is positively associated with their satisfaction.

H6: Users' perceived usefulness of m-commerce approach is positively associated with their continuance intention.

H7: Users' satisfaction with m-commerce approach is positively associated with their continuance intention.

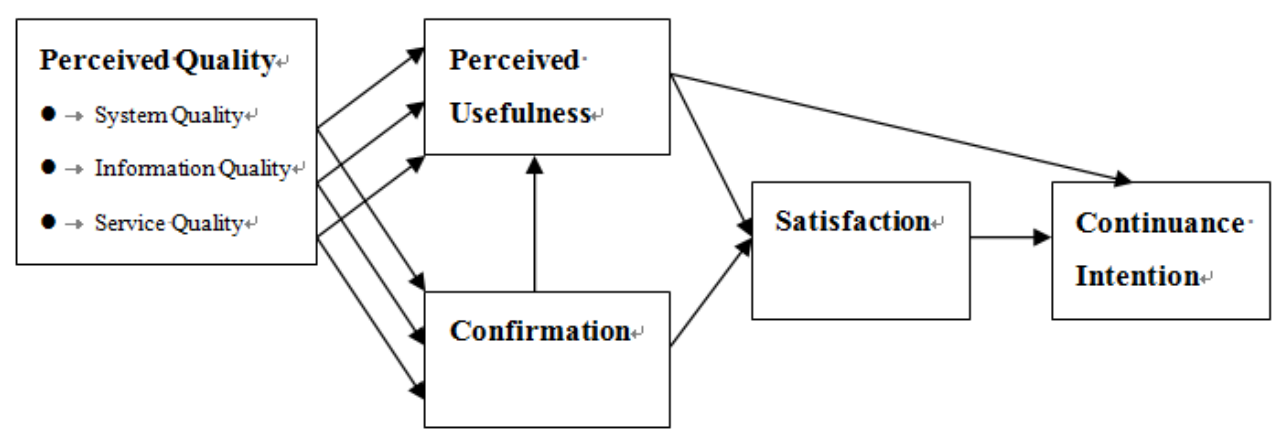

Figure 1. Research model

\section{Methodology}

\subsection{Measurement}

This study measures seven constructs: system quality, information quality, service quality, confirmation, perceived usefulness, satisfaction, and continuance intention (Appendix A). These items were taken from prior IS studies $^{5,8,18,16,36,41,42}$ and reworded to specifically relate to online barter. All items were measured using 5-point Likert scales anchored from 1 (strongly disagree) to 5 (strongly agree). The initial version of the instrument was pre-tested for content validity at a meeting between six $\mathrm{m}$-commerce experts and users. Participants examined the survey instrument and were asked to comment on the wording of each item, its length, and format.

\subsection{Sampling}

The empirical data presented in this study were collected using an Internet survey, and the messages advertising this survey were posted in various public forums. In addition, e-mails were sent to mobile phone users who were continuing educating students at three universities. By the cut-off date, a convenience sample of 416 responses was collected. Among the 416 responses received, 10 were discarded as incomplete, yielding 406 usable responses. Table 1 shows the major characteristics of the 406 subjects. 
Table 1. Demographic profile of the sample

\begin{tabular}{llll}
\hline Variable & Category & Number & Percentage \\
\hline Gender & Male & 216 & 53.2 \\
& Female & 190 & 46.8 \\
\hline Age & 20 or under & 10 & 2.5 \\
& $21-20$ & 138 & 34.0 \\
& $31-40$ & 216 & 53.2 \\
& $41-50$ & 33 & 8.1 \\
& 51 or more & 9 & 2.2 \\
\hline Education & Middle School or less & 2 & 0.5 \\
& High School & 20 & 4.9 \\
& University & 300 & 73.9 \\
& Graduate School & 84 & 20.7 \\
\hline Occupation & Student & 32 & 7.9 \\
& Public Service & 25 & 6.2 \\
& Technology & 141 & 34.7 \\
& Bank and Finance & 29 & 7.1 \\
& Industry & 66 & 16.3 \\
& Fishery and Farming & 5 & 1.2 \\
& Service & 108 & 26.6 \\
\hline Income (US\$) & 660 or less & 41 & 10.1 \\
& 660-1,000 & 71 & 17.5 \\
& 1,001-1,650 & 177 & 43.6 \\
& 1,651-2,350 & 74 & 18.2 \\
& 2,351 or more & 43 & 10.6 \\
\hline
\end{tabular}

\subsection{Data analyses}

Following the two-step approach recommended by Anderson and Gerbing ${ }^{51}$, this study first assesses the reliability and validity of the measurement model, and then examines the structural model.

All construct scales were analyzed using Cronbach's $\alpha$ first to determine if the scales exhibited acceptable levels of reliability ${ }^{52}$. Table 2 showed that Cronbach's $\alpha$ values of all seven constructs exceeded 0.7, indicating acceptable reliability. The reliability can also be checked if the CR value was 0.70 or higher and the AVE value was 0.50 or higher. All factors met both criteria (Table 2). Convergent and discriminant validity were assessed using confirmatory factor analysis (CFA) ${ }^{53,54}$. Convergent validity can be evaluated by examining the factor loadings from the confirmatory factor analysis. According to Hair, Anderson, Tatham and Black' ${ }^{55}$ suggestion that factor loadings greater than 0.50 were considered 
to be very significant. All the factor loadings were higher than 0.7 in this study. These results provide strong evidence of convergent validity. For discriminant validity, Table 3 showed the inter-construct correlations and the square roots of the AVE. The square root of the AVE was higher than their shared variances. The results confirmed the discriminant validity of the model constructs.

Table 2. Scale reliabilities

\begin{tabular}{lcccccc}
\hline \multicolumn{1}{c}{ Construct } & Items & $\begin{array}{c}\text { Standardized } \\
\text { Loading }\end{array}$ & $\begin{array}{c}T \\
\text { value }\end{array}$ & $\begin{array}{c}\text { Cronbach's } \\
\alpha\end{array}$ & CR & AVE \\
\hline Perceived & SEQ1 & 0.87 & 22.00 & .933 & 0.935 & 0.783 \\
Service & SEQ2 & 0.91 & 23.60 & & & \\
Quality & SEQ3 & 0.88 & 22.45 & & & \\
(SEQ) & SEQ4 & 0.88 & 22.13 & & & \\
\hline Perceived & SYQ1 & 0.84 & 20.35 & .897 & 0.893 & 0.677 \\
System & SYQ2 & 0.79 & 18.53 & & & \\
Quality & SYQ3 & 0.83 & 19.88 & & & \\
(SYQ) & SYQ4 & 0.83 & 20.11 & & & \\
\hline Perceived & INQ1 & 0.78 & 18.18 & .903 & 0.905 & 0.657 \\
Information & INQ2 & 0.85 & 21.02 & & & \\
Quality & INQ3 & 0.78 & 18.46 & & & \\
(INQ) & INQ4 & 0.85 & 20.73 & & & \\
& INQ5 & 0.79 & 18.62 & & & \\
\hline Continuance & CIN1 & 0.88 & 22.42 & .935 & 0.933 & 0.823 \\
Intention & CIN2 & 0.90 & 23.04 & & & \\
(CIN) & CIN3 & 0.94 & 25.13 & & & \\
\hline Satisfaction & SAT1 & 0.78 & 18.61 & .904 & 0.916 & 0.786 \\
(SAT) & SAT2 & 0.93 & 24.37 & & & \\
& SAT3 & 0.94 & 24.12 & & & \\
\hline Confirmation & COF1 & 0.79 & 18.43 & .866 & 0.870 & 0.690 \\
(COF) & COF2 & 0.87 & 21.04 & & & \\
& COF3 & 0.83 & 19.78 & & & \\
\hline Perceived & PUS1 & 0.87 & 21.62 & .904 & 0.908 & 0.712 \\
Usefulness & PUS2 & 0.90 & 22.74 & & & \\
(PUS) & PUS3 & 0.78 & 18.43 & & & \\
& PUS4 & 0.82 & 19.84 & & & \\
\hline
\end{tabular}

LISREL 8.51 software was adopted to estimate the structural model and test model hypotheses. Figure 2 showed the path coefficients and the explained variance of a dependent variable $\left(R^{2}\right)$. Table 4 listed the fit indices of the model. The value of $\chi^{2}$ is 688.21 , the degree of freedom (d.f.) is 285 , 
$\chi 2 /$ d.f. equals 2.38, the comparative fit index (CFI) reaches 0.96 , the normed fit index (NFI) is 0.93 , and the root mean square error of approximation (RMSEA) is 0.059. All indices fit well except the GFI, which is 0.88 , and the AGF is slightly lower than the commonly cited criterion of $0.9^{55}$. However, because a GFI higher 0.8 can be interpreted as a reasonable $\mathrm{fit}^{56,57}$, the proposed model provides an adequate fit.

Table 3. Correlation matrix and discriminant assessment

\begin{tabular}{cccccccc}
\hline & PUS & COF & SAT & CIN & INQ & SYQ & SEQ \\
\hline PUS & 0.84 & & & & & & \\
COF & 0.6 & 0.83 & & & & & \\
SAT & 0.72 & 0.73 & 0.88 & & & & \\
CIN & 0.70 & 0.63 & 0.83 & 0.90 & & & \\
INQ & 0.65 & 0.68 & 0.73 & 0.64 & 0.81 & & \\
SYQ & 0.61 & 0.65 & 0.61 & 0.57 & 0.69 & 0.82 & \\
SEQ & 0.46 & 0.69 & 0.57 & 0.43 & 0.73 & 0.71 & 0.88 \\
\hline
\end{tabular}

Note: Diagonal elements are the square root of AVE. PUS: Perceived Usefulness; COF: Confirmation; SAT: Satisfaction; CIN: Continuance Intention; INQ: Information Quality; SYQ: System Quality; SEQ: Service Quality

Table 4. Fit Indices of the Structural Model

\begin{tabular}{lcccccc}
\hline Fit indices & $\chi 2 /$ d.f & RMSEA & CFI & NFI & GFI & AGFI \\
\hline Recommended values & $<3$ & $<0.08$ & $>0.90$ & $>0.90$ & $>0.80$ & $>0.80$ \\
Model values & 2.38 & 0.059 & 0.96 & 0.93 & 0.88 & 0.86 \\
\hline
\end{tabular}

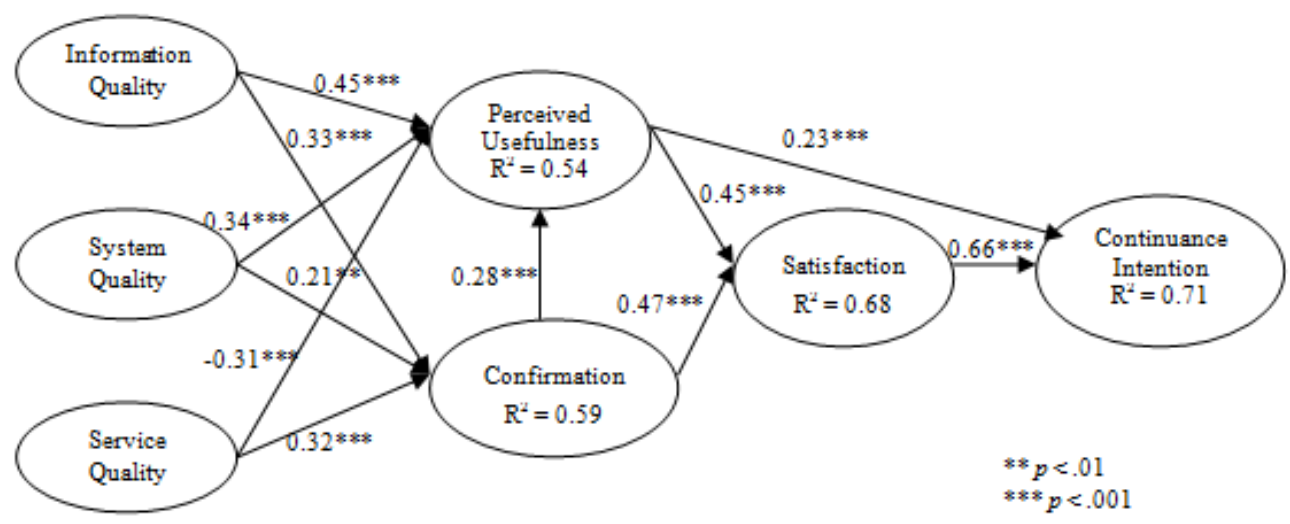

Figure 2. Results of structural modeling analysis

\subsection{Results}


The results of this study support all hypotheses but H2c. Information and service qualities are significantly positively influenced by confirmation at the 0.001 level, whereas system quality is affected significantly at the 0.01 level. Thus, H1a, H1b, and H1c are supported. Information and system qualities are significantly related to perceived usefulness at the 0.001 level, supporting $\mathrm{H} 2 \mathrm{a}$ and $\mathrm{H} 2 \mathrm{~b}$. However, perceived service quality is negatively related to perceived usefulness, and $\mathrm{H} 2 \mathrm{c}$ is therefore rejected. As expected by previous studies, confirmation to perceived usefulness, confirmation and perceived usefulness to satisfaction, and perceived usefulness and satisfaction to continuance intention are all significantly related at the 0.001 level, supporting $\mathrm{H} 3, \mathrm{H} 4, \mathrm{H} 5, \mathrm{H} 6$, and $\mathrm{H} 7$.

The three dimensions of quality $\left(R^{2}=0.59\right)$ capture $59 \%$ of the variance of user's confirmation, whereas $54 \%$ of perceived usefulness was captured by its three antecedents. Confirmation and usefulness heavily influence customer satisfaction $\left(R^{2}=0.68\right)$ with almost equal importance. Perceived usefulness and satisfaction $\left(R^{2}=0.71\right)$ capture $71 \%$ of the variation of user's continuance intention, representing highly explanatory power of the ECM in m-commerce.

\section{DISCUSSION}

The major contribution of this study is that it combines the IS success model with the ECM and applies the resulting model to the m-commerce context with good results. This study proposes that perceived quality is an indispensable antecedent of continuance intention on m-commerce, and is largely supported by empirical data. Unlike previous research ${ }^{2,34,41,42}$, this study shows that perceived quality is not directly related to satisfaction (which in turn influences continued usage intention), but is mediated by confirmation and perceived usefulness, as suggested by the $\mathrm{ECM}^{16}$.

This study adopts three quality dimensions of information, system, and service to investigate their effects on confirmation. Consistent with findings from online shopping ${ }^{40}$, perceived information and system qualities are positively related to confirmation. Service quality, the extended dimension adapted to B2C e-commerce success in DeLone and McLean's model ${ }^{22}$, also influences user's confirmation. The results of this study show that all three quality dimensions can be applied to the m-commerce context.

Perceived information and system qualities are also positively related to perceived usefulness, as in e-commerce studies ${ }^{42,46}$. However, service quality has a negative relationship with usefulness. The main reason for this unexpected finding may be that consumers perceive m-commerce as not "useful" if they require more services from m-commerce providers after initial adoption. Perceived usefulness in the ECM represents a new level of 
expectations (high or low) after initial usage experience (confirmed or disconfirmed $)^{16}$. In the mobile communication environment, shopping tasks should be accomplished within a shorter timeframe, despite much outside interference. Thus, information and system qualities are important. In this case, service quality, defined as the support delivered by the service provider $^{22}$, may be unnecessary or even annoying if one has already experienced (confirmed) the benefits of m-commerce and formed a higher expectation (perceived usefulness) of quick and timely purchase.

\section{MANAGERIAL IMPLICATIONS}

The findings of this study have major implications for m-commerce practice. Although many retailers have seized the opportunity to go "mobile," many sites have slow load times, out-of-date information, and complex navigation ${ }^{58}$. The lack of information, system, and service qualities can be devastating for enterprises that have launched mobile business because initial users are confirmed or disconfirmed based on quality factors. Confirmed or positive disconfirmed consumers become satisfied consumers, and in turn form a repurchase intention, whereas dissatisfied users discontinue further use ${ }^{10}$ and are lost forever. Therefore, it is paramount for anyone who wants to engage in mobile business to offer abundant and up-to-date product and service information to ensure connection quality and to follow up with quality customer service.

The empirical results of this study suggest that service quality is irrelevant if one wants to turn a repurchase user into a loyal customer. Service quality may even have negative consequences. Thus, the role of information quality and system quality is even more important. Of these two determinants, the importance of information quality in retaining mobile customers cannot be underestimated. It is the most influential factor that is perceived by consumers as useful. Mobile content should be at least complete and easy to understand ${ }^{22}$, which is a difficult task if we want to display it adequately in a relative small screen ${ }^{23}$.

Another contribution of this study to mobile practitioners is that it adopts the three quality dimensions of DeLone and McLean's model. Compared to new quality constructs with similar definitions (e.g., content quality vs. information quality) developed specifically for m-commerce, information quality, system quality, and service quality are more comprehensible and easier to implement because they originated from IS and e-commerce studies, which share many of the same attributes with technical and marketing perspectives. 


\section{LIMITATIONS AND FUTURE RESEARCH}

The self-selection issue poses a problem in the questionnaire survey process, and is a methodological concern in this study. It is especially true when we conduct any consumer behavior research because no general mobile shoppers' "population" can be identified. However, we think the sample in this study is representative of general mobile consumers because its demographic distributions are similar to those of mobile phone users.

Information, system, and service qualities are key antecedents of the ECM. Future research may consider if there is any variation among these three qualities for different type of products, such as physical goods, services, or software downloads. With so much app-store hype among mobile phone users, software downloads may be a topic worthy of separate investigation in m-commerce.

\section{ACKNOWLEDGMENT}

This research was funded by the Ministry of Science and Technology (MSC) under Grant Number 100-2410-H-231-009.

\section{REFERENCES}

[1] M. Khilfa, and K.N. Shen, Drivers for transactional for B2C m-commerce adoption: Extended theory of planned behavior. The Journal of Computer Information System, 48(3), p111-117, 2008.

[2] eMarketer 2011, US m-commerce sales to grow $91 \%$ to $\$ 6.7$ billion in 2011. Retrieved on May 20, 2012, from http://www.emarketer.com/PressRelease.aspx? $\mathrm{R}=1008716$.

[3] ITU Report 2011, The world in 2011: ICT facts and figure [online] Report from International Telecommunication Union (ITU). Retrieved on May 14, 2012, from http://www.itu.int/ITU-D/ict/facts/2011/material/ICTFactsFigures2011. pdf.

[4] NCC Statistical Charts 2011, Telecommunication figure in 2011' Report from National Communication Committee in Taiwan. Retrieved on May 14, 2012, from http://www.ncc.gov.tw/english/files/12050/301_1026_120508_1.

[5] M.C. Hung, H.G. Hwang, and T.C. Hsieh, An exploratory study on the continuance of mobile commerce: An extended expectation-confirmation model of information system use. International Journal of Mobile Communication, 5(4), p409-422, 2007. http://dx.doi.org/10.1504/IJMC.2007.012788.

[6] J.H. Wu, and S.C. Wang, What drives mobile commerce? An empirical evaluation of the revised technology acceptance model. Information \& 
management, $\quad 42(5), \quad$ p719-729, 2005. http://dx.doi.org/10.1016/j.im.2004.07.001.

[7] X. Wu, Q. Chen, L. Sheng, and Y. Wang, A conceptual model of $\mathrm{m}$-commerce customers' continuance intention based on the customers' perceived value. International Journal of Mobile Learning and Organization, 3(3), p243-257, 2009. http://dx.doi.org/10.1504/IJMLO.2009.026311.

[8] C.S. Lin, S. Wu, and R.J. Tsai, Integrating perceived playfulness into expectation-confirmation model for web portal context. Information \& Management, 42(5), p683-693, 2005. http://dx.doi.org/10.1016/j.im.2004.04.003.

[9] A.Y.L. Chong, Understanding mobile commerce continuance intention: An empirical analysis of Chinese consumers. The Journal of Computer Information Systems, 53(4), p22-30, 2013.

[10] R.L. Oliver, A cognitive model of the antecedents and consequences of satisfaction decisions. Journal of Marketing Research, 17(4), p460-469, 1980. http://dx.doi.org/10.2307/3150499.

[11] F.D. Davis, R.P. Bagozzi, and P.R. Warshaw, User acceptance of computer technology: A comparison of two theoretical models. Measurement Science, 35(8), p982-1003, 1989. http://dx.doi.org/10.1287/mnsc.35.8.982.

[12] S.J. Hong, J.Y.L. Thong, and K.Y. Tam, Understanding continued information technology usage behavior: A comparison of three models in the context of mobile Internet. Decision Support Systems, 42(3), p1819-1834, 2006. http://dx.doi.org/10.1016/j.dss.2006.03.009.

[13] Y.S. Kang, S. Hong, and H. Lee. Exploring continued online service usage behavior: The roles of self-image congruity and regret. Computer in Human Behavior, 25(1), p111-122, 2009. http://dx.doi.org/10.1016/j.chb.2008.07.009.

[14] M.C. Lee, Explaining and predicting users' continuance intention toward e-learning: An extension of expectation-confirmation model. Computer \& Education, 54(2), p506-516, 2010. http://dx.doi.org/10.1016/j.compedu.2009.09.002.

[15] S. Lee, Mobile Internet services from consumers' perspectives. International Journal of Human-Computer Interaction, 25(5), p390-413, 2009. http:/dx.doi.org/10.1080/10447310902865008.

[16] A. Bhattacherjee, Understanding information system continuance: An expectation-confirmation model. MIS Quarterly, 25(3), p351-370, 2001. http://dx.doi.org/10.2307/3250921.

[17] M. Limayem, S.G. Hirt, and C.M.K. Cheung, How habit limits the predictive power of intention: The case of information systems continuance. MIS Quarterly, 31(4), p705-737, 2007.

[18] M. Chae, J. Kim, H. Kim, and H. Ryu, Information quality for mobile 
internet services: A theoretical model with empirical validation. Electronic Markets, $12 \quad$ (1), p38-46, 2002. http://dx.doi.org/10.1080/101967802753433254.

[19] A. O'Cass, and J. Carlson, An empirical assessment of consumers' evaluations of web site service quality: Conceptualizing and testing a formative model. Journal of Service Marketing, 26(6), p419-434, 2012. http://dx.doi.org/10.1108/08876041211257909.

[20] C.L. Corritore, B. Kracher, and S. Wiedenbeck, On-line trust: Concepts, evolving themes, a model. International Journal of Human-Computer Studies, 58(6), p737-58, 2003. http://dx.doi.org/10.1016/S1071-5819(03)00041-7.

[21] W.H. Delone, and E.R. McLean, Information systems success: The Quest for the dependent variables. Information Systems Research, 3(1), p60-95, 1992. ttp://dx.doi.org/10.1287/isre.3.1.60.

[22] W.H. Delone, and E.R. McLean, The DeLone and McLean Model of information systems success: A ten-year update. Journal of Management Information Systems, 19(4), p9-30, 2003.

[23] K. Siau, and Z. Shen, Building customer trust in mobile commerce. Communications of the ACM, 46(4), p91-94, 2003. http://dx.doi.org/10.1145/641205.641211.

[24] M. Li., Z.Y. Dong, and X. Chen, Factors influencing consumption experience of mobile commerce. Internet Research, 22(2), p120-141, 2012. http://dx.doi.org/10.1108/10662241211214539.

[25] T. Kamba, S.A. Elson, T. Harpold, T. Stamper, and P. Sukaviriya, Using small screen space more efficiently. In M. Tauber (Ed.), Proceedings of the 1996 ACM Conference on Human Factors in Computing Systems (CHI2000) (p383-390). Vancouver, British Columbia, Canada: ACM press. http://dx.doi.org/10.1145/238386.238582.

[26] X. Li, Buddy-finding in the mobile environment. Technovation, 25(9), p1017-1023, 2005. http://dx.doi.org/10.1016/j.technovation.2004.02.006.

[27] M. Kleijnen, M. Wetzels, and K. de Ruyter, Consumer acceptance of wireless financial. Journal of Financial Service Marketing, 8(3), p206-217, 2004. http://dx.doi.org/10.1057/palgrave.fsm.4770120.

[28] C.E. Shannon, and W. Weaver, The mathematical theory of communication. Urbana, IL: University of Illinois Press, 1949.

[29] R.O. Mason, Measuring information output: A communication system approach. Information \& Management, 1(4), p803-838, 1978. http://dx.doi.org/10.1016/0378-7206(78)90028-9.

[30] L.F. Pitt, R.T. Watson, and C.B. Kavan, Service quality: A measure of information systems effectiveness. MIS Quarterly, 19(2), p173-187, 1995. http://dx.doi.org/10.2307/249687.

[31] L.A. Halawi, R.V. McCarthy, and J.E. Aronson, An empirical 
investigation of knowledge management systems' success. The Journal of Computer Information systems, 48(2), p121-135, 2007.

[32] W.H. DeLone, and E.R. McLean, Measuring e-commerce success: Applying the DeLone and McLean Information Systems Success Model. International Journal of Electronic Commerce, 9(1), p31-47, 2004.

[33] V. Khayun, and P. Ractham, Accessing e-excise success of Delone and Mclean' Model. The Journal of Computer Information Systems, 52(3), p31-40, 2012.

[34] H.H. Kuan, G. W. Bock, and V. Vathanophas, Comparing the effects of website quality on customer initial purchase and continued purchase at e-commerce websites. Behaviour \& Information Technology, 27(1), p3-16, 2008. http://dx.doi.org/10.1080/01449290600801959.

[35] R.L. Oliver, Effect of expectation and disconfirmation on postexposure product evaluations: An alternative interpretation. Journal of Applied $\begin{array}{lll}\text { Psychology, 62(4), } 1977 . & \text { p480-486, }\end{array}$ http://dx.doi.org/10.1037//0021-9010.62.4.480.

[36] R.A. Spreng, and R.W. Olshavsky, A desires congruency model of consumer satisfaction. Journal of the Academy of Marketing Science, 21(3), p169-177, 1993. http://dx.doi.org/10.1177/0092070393213001.

[37] J.Y.L. Thong, S.J. Hong, and K.Y. Tam, The effect of post-adoption beliefs on the expectation-confirmation model for information technology continuance. International Journal of Human-Computer Studies, 64(9), p799-810, 2006. http://dx.doi.org/10.1016/j.ijhcs.2006.05.001.

[38] C.M. Chiu, M.H. Hsu, S.Y. Sun, T.C. Lin, and P.C. Sun, Usability, quality, value and e-learning continuance decisions. Computers and Education, $\quad 45(4), \quad$ p399-416, 2005. http://dx.doi.org/10.1016/j.compedu.2004.06.001.

[39] C.H. Yen, and H.P. Lu, Factors influence online auction repurchase intention. Internet Research, 18(1), p7-25, 2008. http://dx.doi.org/10.1108/10662240810849568.

[40] V. McKinney, K. Yoon, and F.M. Zahedi, The measurement of Web-customer satisfaction: An expectation and disconfirmation approach. Information System Research, 13(3), p296-315, 2002. http://dx.doi.org/10.1287/isre.13.3.296.76.

[41] A. Rai, S. Lang, and R. Welker, Assessing the validity of IS success models: An empirical test and theoretical analysis. Information Systems Research, 13(1), p50-69,

2002. http://dx.doi.org/10.1287/isre.13.1.50.96.

[42] I. Brown, and R. Jayakody, B2C e-commerce success: A test and validation of a revised conceptual model. The Electronic Journal Information System Evaluation, 12(2), p129-148, 2009. 
[43] T. Zhou, Y. Lu, and B. Wang, The relative importance of Website design quality and service quality in determining consumers' online repurchase behavior. Information System Management, 26(4), p327-337, 2009. http://dx.doi.org/10.1080/10580530903245663.

[44] P.K. Hellier, G.M. Geursen, R.A. Carr, J.A. Rickard, Customer repurchase intention: A general structural equation model. European Journal of Marketing, 37(11/12), p1762-1800, 2003. http://dx.doi.org/10.1108/03090560310495456.

[45] Y.S. Wang. Assessing e-commerce systems success: A respecification and validation of the DeLone and McLean model of IS success. Information Systems Journal, 18(5), p529-557, 2008. http://dx.doi.org/10.1111/j.1365-2575.2007.00268.x.

[46] A. Lederer, D. Maupin, M. Sena, and Y. Zhuang, The technology acceptance model and the World Wide Web. Decision Support Systems, 29(3), p269-282, 2000. http://dx.doi.org/10.1016/S0167-9236(00)00076-2.

[47] P. Seddon, A respecification and extension of the DeLone and Mclean Model of IS success. Information Systems Research, 8(3), p240-253, 1997. http://dx.doi.org/10.1287/isre.8.3.240.

[48] L. Harris, and M. Goode, The four levels of loyalty and the pivotal role trust: A study of online service dynamics. Journal of Retailing, 80(2), p139-158, 2004. http://dx.doi.org/10.1016/j.jretai.2004.04.002.

[49] T. Zhou, Examining the critical success factors of mobile website adoption. Online Information Review, 35(4), p636-652, 2011. http://dx.doi.org/10.1108/14684521111161972.

[50] M. Choi, E.K. Lee, and M.C. Park, An empirical study on the determinants of repurchase intention in Korean mobile Internet services. Paper presented at the International Telecommunications Society, Asia-Australian Reginal Conference, Perth, Australia, June 22-24, 2003. http://dx.doi.org/10203/54386.

[51] J.C. Anderson, and D.W. Gerbing, Structural equation modeling in practice: A review and recommended two-step approach. Psychological Bulletin, 103(2), p411-423, 1988. http://dx.doi.org/10.1037/0033-2909.103.3.411.

[52] J.C. Nunnally, Psychometric theory. New York, NY: McGraw-Hill, 1978.

[53] C. Fornell, M.D. Johnson, E.W. Anderson, J. Cha, and B.E. Bryant, The American customer satisfaction index: Natural, purpose, and findings. Journal of Marketing, 6(4), p7-18, 1996. http://dx.doi.org/10.2307/1251898.

[54] R. Bagozzi, and Y. Yi, On the use of structural equation models experimental designs. Journal of Marketing, 26(3), p271-285, 1989. http://dx.doi.org/10.2307/3172900. 
[55] J.F. Hair, R.E. Anderson, R.L. Tatham and W.C. Black, Multivariate data analysis ( $5^{\text {th }}$ ed.). Upper Saddle River, NJ: Prentice Hall, 1998.

[56] W.J. Doll, W. Xia, and G. Torkzadeh, A confirmation of factor analysis of the end-user computer satisfaction instrument. MIS Quarterly, 18(4), p453-461, 1994. http://dx.doi.org/10.2307/249524.

[57] K. Jöreskog and D. Sörbom, LISREL 8: User's reference guide (Version 8.30). Chicago: Scientific Software International, 1996.

[58] 2ergo 2011, Only 58\% of top U.S. retailers have a mobile website and $27 \%$ lack a mobile presence altogether, according to research by 2ergo. Retrieved on May 20, 2012 from http://www.2ergo.com/news-events/news/only-58-of-top-us-retailers-h ave-a-mobile-website-and-27-lack-a-mobile-presence-altogether,-accor ding-to-research-by-2ergo/.

\section{APPENDIX A}

\begin{tabular}{|c|c|c|}
\hline Construct & Measurement items & Source \\
\hline $\begin{array}{l}\text { Perceived } \\
\text { usefulness }\end{array}$ & $\begin{array}{l}\text { 1. I find mobile commerce services } \\
\text { useful in my daily life. } \\
\text { 2. Using mobile commerce services } \\
\text { helps me accomplish things more } \\
\text { quickly. } \\
\text { 3. Using mobile commerce services } \\
\text { increase my productivity. } \\
\text { 4. Using mobile commerce services } \\
\text { helps me performance things } \\
\text { more conveniently. }\end{array}$ & $\begin{array}{l}\text { Moon and } \\
\text { Kim(2001); } \\
\text { Thong et al.(2006) }\end{array}$ \\
\hline Confirmation & $\begin{array}{l}\text { 1. My experience with using the } \\
\text { mobile commerce services was } \\
\text { better than what I expect. } \\
\text { 2. The service level provide by the } \\
\text { mobile commerce services was } \\
\text { better than what I expected. } \\
\text { 3. Overall, most of my expectation } \\
\text { from using mobile commerce } \\
\text { services were confirmed. }\end{array}$ & $\begin{array}{l}\text { Bhattacherjee } \\
\text { (2001) }\end{array}$ \\
\hline
\end{tabular}




\section{APPENDIX A (Cont.)}

\begin{tabular}{|c|c|c|}
\hline Construct & Measurement items & Source \\
\hline Satisfaction & $\begin{array}{l}\text { 1. I am satisfied with decision on } \\
\text { the use of mobile commerce } \\
\text { services. } \\
\text { 2. My choice to use the mobile } \\
\text { commerce services was a wise } \\
\text { one. } \\
\text { 3. I think I did the right thing by } \\
\text { deciding to use my mobile } \\
\text { commerce services. }\end{array}$ & $\begin{array}{l}\text { Spreng and } \\
\text { Olshavsky(1993); } \\
\text { Lin et al.(2005 }\end{array}$ \\
\hline $\begin{array}{l}\text { Continuance } \\
\text { intention }\end{array}$ & $\begin{array}{l}\text { 1. I intent to continue using the } \\
\text { mobile commerce services in the } \\
\text { future. } \\
\text { 2. I will always try to use mobile } \\
\text { commerce services in my daily } \\
\text { life. } \\
\text { 3. I will keep using mobile } \\
\text { commerce services as regularly } \\
\text { as I do now. }\end{array}$ & Thong et al.(2006) \\
\hline $\begin{array}{l}\text { Perceived } \\
\text { information } \\
\text { quality }\end{array}$ & $\begin{array}{l}\text { 1. M-commerce sites provide the } \\
\text { precise information I need. } \\
\text { 2. } \begin{array}{l}\text { M-commerce sites provide } \\
\text { responses to questions and } \\
\text { queries that are exactly what I } \\
\text { need. }\end{array} \\
\text { 3. M-commerce sites provide } \\
\text { sufficient information to enable } \\
\text { me to do my tasks. } \\
\text { 4. I am satisfied with the accuracy } \\
\text { of information provided by } \\
\text { m-commerce sites. }\end{array}$ & $\begin{array}{l}\text { Brown and } \\
\text { Jayakody (2009) }\end{array}$ \\
\hline
\end{tabular}




\section{APPENDIX A (Cont.)}

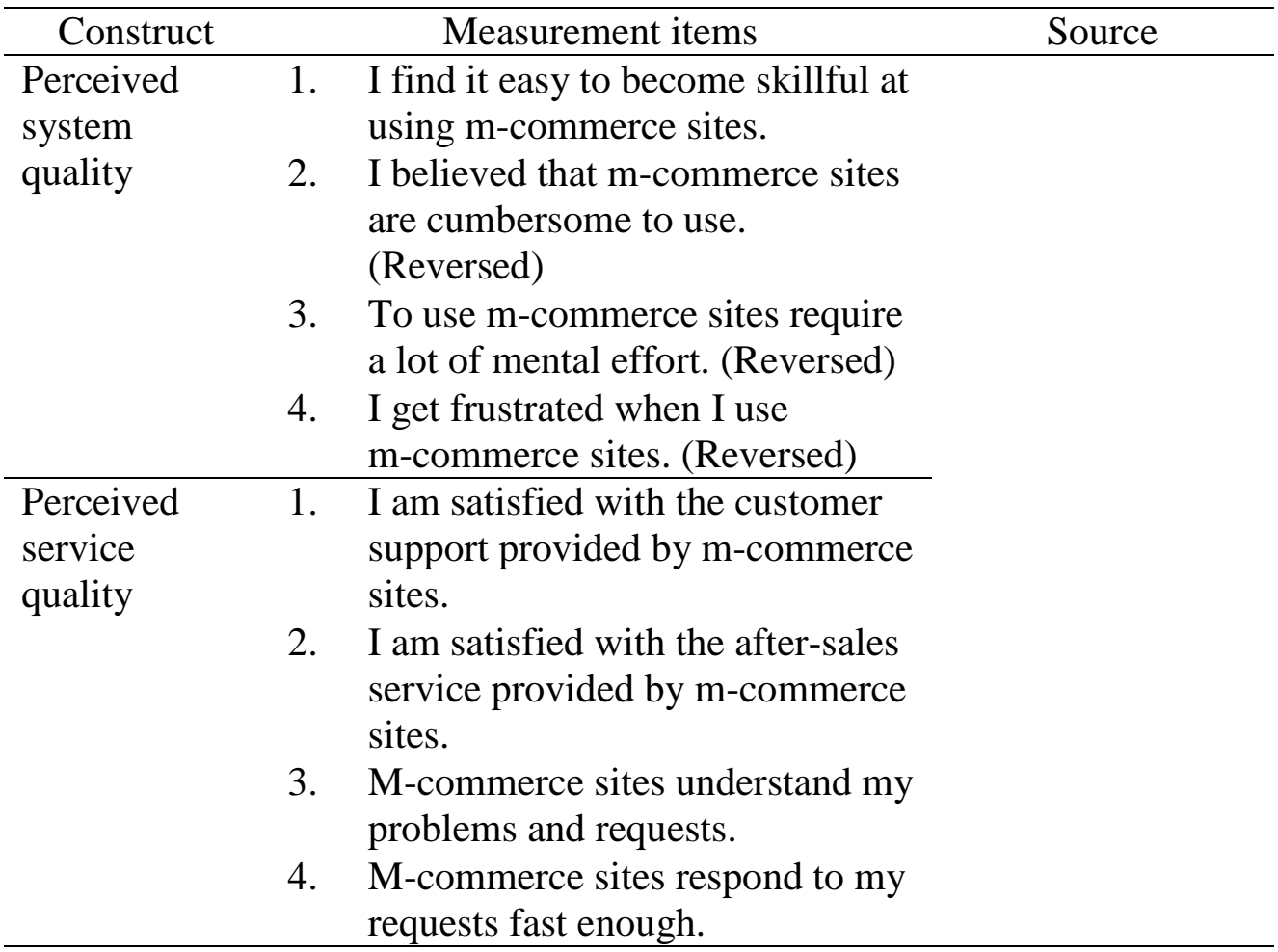

